\title{
Functional Régulation Triad of Mitosis, Apoptosis and Thigmotropism of Survivin in Cutaneous Malignant Melanoma
}

\author{
Gérald E Piérard ${ }^{1 *}$, Claudine Piérard-Franchimont ${ }^{2}$, Philippe Humbert ${ }^{3}$, Jean-Luc Nizet ${ }^{4}$, Philippe \\ Delvenne $^{2}$ \\ ${ }^{1}$ Laboratory of Skin Bioengineering and Imaging, Department of Clinical Sciences, University of Liège, 4000 Liège, Belgium \\ ${ }^{2}$ Department of Dermatopathology, University Hospital of Liège, Liège, Belgium \\ ${ }^{3}$ Centre d'Etudes et de Recherche sur le Tégument (CERT), INSERM UMR1098, SFR FED 4234 IBCT, University of Franche-Comté, Besançon, France \\ ${ }^{4}$ Department of Plastic Surgery, University Hospital of Liège, Liège, Belgium
}

Received: August 03, 2016; Accepted: September 09, 2016; Published: September 19, 2016

*Corresponding author: Gérald E Piérard, Department of Dermatopathology, University Hospital of Liège, BE-4000 Liège, Belgium, E-mail : gerald.pierard@ulg.ac.be

\begin{abstract}
Growth of sporadic Cutaneous Malignant Melanoma (CMM) depends on the combination of the mean tumoral cell cycle time, the growth fraction and the kinesis of the apoptotic programmed cell death. A series of pro-apoptotic and anti-apoptotic regulators have been identified. This review discusses the established mitotic and cytoprotective properties of survivin, and its potential role in CMM development and progression. Other functional properties of survivin are considered, namely enhancement of cellular motility, and thigmotropism which underly the role of this inhibitor of apoptosis protein in promoting overt SMM metastases.
\end{abstract}

Keywords: Cutaneous Malignant Melanoma; Programmed Cell Death; Apoptosis; Thigmotropism; Mitotic Activity; Metastasis

\section{Introduction}

The incidence of sporadic Cutaneous Malignant Melanoma (CMM) is rapidly expanding worldwide, particularly in developed countries $[1,2]$. The tumoral growth, progression, and stealthy spread are mainly modulated by the balance between the tumoral cell renewal rate [3-5] and the apoptosis process. The cell cycle is characterized by a cellular sequential set of molecular events involved in DNA replication and cell division. In a sustained replicative cell system the elapsed time between any given cell division and the next one corresponds to the cell cycle time $\left(\mathrm{T}_{\mathrm{c}}\right)$. Following mitosis completion, the cell cycle usually enters the G1 phase. However, at a restriction point of this early stage of the replication cycle, the cell either proceeds through the cycle and divides, or enters into a nondividing or quiescent (GO) phase, thereby reducing the proportion of proliferating cells among the neoplastic population. The Growth Fraction (GF) is defined as the proportion of the cell population actually progressing through the cell cycle. GF is reduced by the cell population in the G0 phase. In addition, cell loss occurs in the dividing and nondividing compartments of the tumor through cell death and metastasis.
Therefore, the global rate of CMM growth depends upon the mean $\mathrm{T}_{c}$, the GF extent, and the amount of any cell loss [4].

Generally, the enlarged germinative compartment and its GF in CMM is indicative of a life-threatening neoplastic progression, and is related to the clinical growth rate of the neoplasm [4]. Such assessment helps distinguishing high risk fast-growing CMM characterized by an enlarged GF from those CMM of lower malignancy that behave as slow-growing or growth-stunted neoplasms associated with a restricted GF [4]. The recruitment and progression of CMM cells in the cell cycle of proliferation are associated with loss of some of their controls normally processed by a series of key regulatory molecules. In addition, all these features are likely conditioned by the presence of CMM stem cells, also referred to as tumor-initiating cells [6].

Some CMM cells undergo self-destruction under programmed cell death [7]. The molecular compounds involved in apoptosis encompass the combination of positive (pro-apoptotic) and negative (anti-apoptotic) regulators [5-7]. The former include p53, Bid, Fas/FasL, Noxa, PUMA, Bax, TNF, TRAIL, PITSLRE, interferons, and c-KIT/SCF. The latter include Bcl-2, Bcl- $\mathrm{X}_{\mathrm{L}^{\prime}}$ Mcl-1, $\mathrm{NF}_{-}{ }_{\mathrm{K}} \mathrm{B}$, survivin, livin, ML-IAP as cell as BRAF activation, and NRAS activation. Alternatively, some molecules such as TRAF-2, c-Myc, endothelins, and integrins exhibit either proor anti-apoptotic effects [7]. Some of these compounds were presented as potential therapeutic agents namely, (a) p53 influencing resistance to chemotherapy; (b) Mcl-1 and Bcl- $\mathrm{X}_{\mathrm{L}}$ overriding apoptosis; (c) TRAIL, exhibiting selective fatal effects on neoplastic cells; (d) $\mathrm{NF}^{-} \mathrm{B}$ downregulation sensitizing cells to TRAIL and TNF; (e) PITSLRE kinase alterations leading to Fas resistance; (f) interferons sensitizing cells to other factors; and (g) some inhibitors of apoptosis proteins (IAP) including survivin [7].

\section{SURVIVIN as an IAP IN CMM}

A number of primary changes in CMM tend to suppress apoptosis. Reduced apoptosis is selected in advanced CMM 
development [8]. Transcription factor $\mathrm{NF}_{\mathrm{K}} \mathrm{B}$ (nuclear factor ${ }_{\mathrm{K}} \mathrm{B}$ ) is a note of convergence of various signals. As BRAF but not NRAS oncogenic activation is commonly accompanied by independent PTEN loss in late CMM, it seems likely that one copy of activated BRAF does not suppress apoptosis so efficiently as activated NRAS.

A small compound of the IAP family is survivin. Its expression is regulated during development. It is widely expressed in fetal tissues and becomes silent in most adult tissues, although it is reexpressed in a number of cancers. Distinct intracellular pools of survivin are dispersed in the cytosol, mitochondriae, and nucleus [8]. These subcellular pools are probably tied to distinct cell functions. Nuclear survivin is present in a large subset of CMM. Such presence is correlated with poor survival [9]. The nuclear pool is linked to survivin function in mitosis, while the cytosolic and mitochondrial pools are involved its antiapoptotic function Globally, in neoplastic cells, survivin is predominantly bound to the inner mitochondrial membrane. This IAP is present in CMM and melanocytic nevi, but not in the regular melanocytes. Following some apoptotic stimuli, this IAP is trafficked from mitochondriae into the cytosol. Surviving binds to caspase 3 and 7 , and is associated with mitotic spindle where it overrides the M/G2 apoptotic checkpoint [10]. Survivin is a Chromosomal Passenger Protein (CPP) [11] interacting with other specific intracellular molecular components [12]. It pronotes migration of the CPP complex from the inner centromere during prometaphase cytokinesis [13]

Moecular profiding has identified survivin as a marker of poor prognosis in cancerology [8]. Disruption of survivin functions, particularly in malignancies leads to a series of cell cycle defects including multipolar mitotic spindles, failure of cytokinesis, and formation of multinucleated cells [7]. The presence of a dominant-negative survivin mutant in CMM cells is responsible for a reduction in DNA content during the M and G2 phases, and an impaired proliferation [7]. In addition, survivin is involved in microtubule spindle organization [14]. Likely, it helps CMM cells with DNA damages to bypass specific cell cycle checkpoints, proceeds with cell division and distinctly exerts its anti-apoptotic function. Survivin anti-apoptotic control follows binding to and stabilizing XIAP, which inhibits caspase-9 [15]. Survivin-mediated inhibition of caspase- 9 further relies on binding to the Hepatitis B X-Interacting Protein (HBXIP) [16]. Upon triggering the apoptotic pathway, the survivin anti-apoptotic function is downregulated following the release of second mitochondrial-derived activator of caspase (Smac) [17]. Survivin blocks both caspase-dependent and -independent cell death in human melanocytes [18]. In CMM cells, this agent protects against caspase-independent apoptosis [19]. The pro-apoptotic activity of dominant-negative survivin mutants in CMM cells reduces CMM tumor growth [7, 20,21].

Cancerogenesis globally involves the successive steps of initiation, promotion and progression phases [22, 23]. In CMM, cell migration, thigmotropism, and tensegrity are likely involved and linked in part to tumor progression and metastasis. The concept of CMM thigmotropism encompasses the complex migration path including the extravascular and (peri) neural spreads. The peculiar involvement of CMM stem cells [6] and the nature of the microenvironmental niche in the thigmotropic process are largely unknown. However, pertinent role of the host milieu and/or the microenvironment in tumorigenesis has also been recognized for CMM [6]. Cell mobility and migration in combination with cell proliferation are activated in both the primary CMM and in the metastatic spread [21, 24, 25]. Cell motility encompasses migration, thigmotropism and invasion, which are key aspects of the metastatic process. They require a set of signalling events both inside CMM cells and in the extracellular matrix for migration of cells within their close microenvironment and to distant sites [26, 27]. Survivin is likely involved in these processes, and possibly plays a role in promoting CMM metastases [21]. Survivin-mediated invasion appears as integrin-independent, but requires activation of nuclear factor (NF) $-\chi B$ and cell motility kinases, Focal Adhesion Kinase (FAK) and Sarcoma-Related (Src) kinase [7, 28]. Such a complex mechanism enhances cell migration, and promotes the invasive pattern of human CMM cells [29]. Promoting CMM cell mobility appears to follow the activation of the protein kinase- $B$ (Akt) signalling pathway, and the upregulation of $\alpha 5$ integrin [21]. Both events follow survivin overexpression in CMM cells [29]. Survivin knockdown by RNAi, under conditions where apoptosis is not induced, further demonstrate that survivin is required for the constitutive migration and invasion of CMM cells [29]. In addition, survivin-mediated promotion of CMM cell invasion depends on activation of the MAPK pathway [21,30].

\section{Conclusion}

The majority of CMM-associated deaths are due to metastases, highlighting the importance of understanding the molecular mechanisms driving CMM and progression. Tumorigenesis and metastatic spread of CMM are largely unpredictable by clinical inspection alone [31] and any site of the body is possibly involves. The main factors linked to the metastatic neoplasm are interacting in different ways among patients. They include cell renewal, apoptosis and thigmotropism. These functions are mediated by a number of molecular controls including the IAP survivin, and some immune functions [32].

The impact of survivin in the overt metastatic CMM spread does not explain the distinct patterns of metastasis distributions in the human body. Locoregional metastases contain tumor in regional lymph nodes and regional cutaneous metastases between the primary tumor and the regional lymph nodes. The latter correspond in called satellite and in-transit metastases. Satellite metastases are separated from the initial stromal tumor by tissue confined around the primary tumor. In-transit metastases are located outside a $2 \mathrm{~cm}$ distance. The distinction between satellite and in-transit metastases remains arbitrary. No substantial difference in survival outcome has been reported between satellite and in-transit metastases have similar prognostic value in the recent AJCC staging system.

The smoldering pattern of CMM metastases is another rare condition were metastases are confined to a retricted body area (the ley) where metastases waxe and wane over time [5,29].

Altogether, the reported features listed in this review indicate that the IAP survivin plays a prominent role in the spreading of 
CMM metastatic cells by influencing cell proliferation, apoptosis and mobility.

\section{Acknowledgements}

No sources of funding were used to assist in the preparation of this manuscript. The authors have no conflicts of interest that are directly relevant to the content of this review. The authors appreciate the excellent secretarial assistance of Magali Caes.

\section{References}

1. Ekwueme DU, Guy GP Jr, Li C, Rim SH, Parelkar P, Chen SC. The health burden and economic costs of cutaneous melanoma mortality by race/ ethnicity-United States, 2000 to 2006. J Am Acad Dermatol. 2011;65(5 Suppl 1):S133-143. doi: 10.1016/j.jaad.2011.04.036

2. Jemal A, Saraiya M, Patel P, Cherala SS, Barnholtz-Sloan J, Kim J, et al. Recent trends in cutaneous melanoma incidence and death rates in the United States, 1992-2006. J Am Acad Dermatol. 2011;65(5 Supp 1):S17-25. doi: 10.1016/j.jaad.2011.04.032

3. Piérard GE, Piérard-Franchimont C, Henry F, Lapière M. The proliferative activity of cells of malignant melanomas. Am J Dermatopathol. 1984;6 suppl:317-323.

4. Piérard GE. Cell proliferation in cutaneous malignant melanoma: relationship with neoplastic progression. Int Scholarly Res Network Dermatol. 2012;2012:828146. doi: 10.5402/2012/828146

5. Piérard-Franchimont C, Hermanns-Lê T, Delvenne P, Piérard GE Dormancy of growth-stunted malignant melanoma: sustainable and smoldering patterns. Oncol Rev. 2014;8(2):54-59. doi: 10.4081/ oncol.2014.252

6. Schatton T, Frank MH. Cancer stem cells and human malignant melanoma. Pigment Cell Melanoma Res. 2008;21(1):39-55. doi:10.1111/j.1755-148X.2007.00427.x.

7. Hussein MR, Haemel AK, Wood GS. Apoptosis and melanoma:molecular mechanisms. J Pathol. 2003;199(3):275-288.

8. Bennett DC. How to make a melanoma: what do we know of the primary clonal events? Pigment Cell Melanoma Res. 2008;21(1):2738. doi: 10.1111/j.1755-148X.2007.00433.x.

9. Chen N, Gong J, Chen X, Meng W, Huang Y, Zhao F, et al. Caspases and inhibitor of apoptosis proteins in cutaenous and mucosal melanoma: expression profile and clinicopathologic significance. Hum Pathol 2009;40(7):950-956. doi: 10.1016/j.humpath.2008.12.001

10. Li F, Ambrosini G, Chu EY, Plescia J, Tognin S, Marchisio PC, et al. Control of apoptosis and mitotic spindle checkpoint by survivin Nature. 1998;396(6711):580-584

11. Bolton MA, Lan W, Powers SE, McCleland ML, Kuang J, Stukenberg PT Aurora B kinase exists in a complex with survivin and INCENP and its kinase activity is stimulated by survivin binding and phosphorylation. Mol Biol Cell. 2002;13(9):3064-3077.

12. Jeyaprakash AA, Klein UR, Lindner D, Ebert J, Nigg EA, Conti E Structure of a Survivin-Borealin-INCENP core complex reveals how chromosomal passengers travel together. Cell 2007.2007;131(2):271285.

13. Uren AG, Wong L, Pakusch M, Fowler KJ, Burrows FJ, Vaux DL, et al. Survivin and the inner centromere protein INCENP show similar cell-cycle localization and gene knockout phenotype. Curr Biol. 2000;10(21):1319-1328.

14. Dohi T, Okada K, Xia F, Wilford CE, Samuel T, Welsh K, et al. An IAP-IAP complex inhibits apoptosis. J Biol Chem. 2004;279(33):34087-34090.
15. Marusawa H, Matsuzawa S, Welsh K, Zou H, Armstrong R, Tamm I, et al. HBXIP functions as a cofactor of survivin in apoptosis suppression. EMBO J. 2003;22(11):2729-2740.

16. Mita AC, Mita MM, Nawrocki ST, Giles FJ. Survivin: key regulator of mitosis and apoptosis and novel target for cancer therapeutics. Clin Cancer Res. 2008;14(16):5000-5005. doi: 10.1158/1078-0432.CCR08-0746.

17. Liu T, Biddle D, Hanks AN, Brouha B, Yan H, Lee RM, et al. Activation of dual apoptotic pathways in human melanocytes and protection by survivin. J Invest Dermatol. 2006;126(10):2247-2256.

18. Liu T, Brouha B, Grossman D. Rapid induction of mitochondrial events and caspase-independent apoptosis in Survivin-targeted melanoma cells. Oncogene. 2004;23(1):39-48.

19. Yan H, Thomas J, Liu T, Raj D, London N, Tandeski T, et al. Induction of melanoma cell apoptosis and inhibition of tumor growth using a cellpermeable Survivin antagonist. Oncogene. 2006;25(52):6968-6974.

20. Piérard GE, Piérard-Franchimont C, Humbert P, Delvenne P. Streamlining molecular pathobiology of malignant melanoma. Clin Res Dermatol. 2016;3(3):1-9.

21. McKenzie JA, Grossman D. Role of the apoptotic and mitotic regulator survivin in melanoma. Anticancer Res. 2012;32(2):397-404.

22. Gaudi S, Messina JL. Molecular bases of cutaneous and uveal melanomas. Pathol Res Int. 2011;2011:159421.

23. Piérard GE, Piérard-Franchimont C, Delvenne P. Malignant melanoma and its stromal nonimmune microecosystem. J Oncol. 2012;2012:584219.

24. Hanahan D, Weinberg RA. The hallmarks of cancer. Cell. 2000;100(1):57-70.

25. Quatresooz P, Piérard-Franchimont C, Noël F, Piérard GE Thigmotropism of malignant melanoma cells. Dermatol Res Pract. 2012;2012:362784

26. Piérard GE, Piérard-Franchimont C, Delvenne P. Malignant melanoma and its stromal nonimmune microecosystem. J Oncol. 2012;2012:584219.

27. Piérard GE, Piérard-Franchimont C, Hermanns-Lê T, Piérard SL Delvenne P. Fractal and spectral analyses of peritumoral skin melanoma. Austin J Canc Clin Res. 2015;2(7):1057.

28. Mehrotra S, Languino LR, Raskett CM, Mercurio AM, Dohi T, Altieri DC. IAP regulation of metastasis. Cancer Cell. 2010;17(1):53-64. doi: 10.1016/j.ccr.2009.11.021.

29. McKenzie JA, Liu T, Goodson AG, Grossman D. Survivin enhances motility of melanoma cells by supporting Akt activation and \{alpha\} 5 integrin up-regulation. Cancer Res. 2010;70(20):7927-7937. doi: 10.1158/0008-5472.CAN-10-0194

30. Piérard GE, Piérard-Franchimont C, Leonard B, Delvenne P. The MAP kianase cascade. A key target for treatments in skin cancerology. Rev Med Liege. 2013;68(12):650-654.

31. Piérard GE, Piérard-Franchimont C, Reginster MA, Quatresooz P. Smouldering malignant melanoma and metastatic dormancy: an update and review. Dermatol Res Pract. 2012;2012:461278.

32. Trivedi MS, Hoffner B, Winkelmann JL, Abbott ME, Hamid O, Carvajal RD. Programmed death 1 immune checkpoint inhibitors. Clin Adv Hematol Oncol. 2015;13(12):858-868. 